\title{
Pathogenicity of two recent Western Mediterranean West Nile virus isolates in a wild bird species indigenous to Southern Europe: the red-legged partridge
}

Elena Sotelo', Ana Valeria Gutierrez-Guzmán², Javier del Amo', Francisco Llorente', Mehdi El-Harrak², Elisa Pérez-Ramírez ${ }^{2}$, Juan Manuel Blanco ${ }^{4}$, Ursula Höfle², Miguel Angel Jiménez-Clavero ${ }^{1 *}$

\begin{abstract}
West Nile virus (WNV) is an emerging zoonotic pathogen whose geographic spread and incidence in humans, horses and birds has increased significantly in recent years. WNV has long been considered a mild pathogen causing self-limiting outbreaks. This notion has changed as WNV is causing large epidemics with a high impact on human and animal health. This has been particularly noteworthy since its introduction into North America in 1999. There, native bird species have been shown to be highly susceptible to WNV infection and disease with high mortalities. For this reason, the effect of WNV infection in North American bird species has been thoroughly studied by means of experimental inoculations in controlled trials. To a lesser extent, European wild birds have been shown to be affected clinically by WNV infection. Yet experimental studies on European wild bird species are lacking. The red-legged partridge (Alectoris rufa) is a gallinaceous bird indigenous to the Iberian Peninsula, widely distributed in South Western Europe. It plays a key role in the Mediterranean ecosystem and constitutes an economically important game species. As such it is raised intensively in outdoor facilities. In this work, red-legged partridges were experimentally infected with two recent WNV isolates from the Western Mediterranean area: Morocco/2003 and Spain/2007. All inoculated birds became viremic and showed clinical disease, with mortality rates of $70 \%$ and $30 \%$, respectively. These results show that Western Mediterranean WNV variants can be pathogenic for some European bird species, such as the red-legged partridge.
\end{abstract}

\section{Introduction}

West Nile virus (WNV) is a neurotropic arthropod-borne virus belonging to the family Flaviviridae, genus Flavivirus. Its natural cycle involves multiple species of birds as amplifying hosts and a wide range of mosquitoes as vectors. Horses and humans are susceptible to WNV disease but generally are not competent amplifying hosts. In the last fifteen years WNV has expanded its geographic range dramatically, and is now considered the most widespread arbovirus in the world [1-3]. In parallel, significant changes have been observed in its epidemiology, virulence and range of host species affected. While originally

\footnotetext{
* Correspondence: majimenez@inia.es

${ }^{1}$ Centro de Investigación en Sanidad Animal del Instituto Nacional de Investigación y Tecnología Agraria y Alimentaria (CISA-INIA), Ctra Algete-El Casar, s/n, 28130 Valdeolmos (Madrid), Spain Full list of author information is available at the end of the article
}

WNV was considered a pathogen of little importance, causing mild disease in humans and horses during sporadic, self-limiting outbreaks; this notion is now changing as WNV is causing large epidemics with thousands of human and veterinary cases with associated morbidity and mortality. Large-scale WNV epidemics have taken place since its introduction in North America in 1999, although vaccination of horses has mitigated the effect of this epizooty in this continent. In Europe, where this disease was disregarded for decades, significant changes have occurred, with an apparent increase in the number of outbreaks. Although enhancement of surveillance for this disease in Europe could in part explain this increase, nevertheless, newly observed patterns such as the raising degree of human involvement and an upsurge of pathogenicity for wild birds [4] might mean that the situation
C Biomed Central 
with regard to this disease in Europe is in fact changing. In particular, wild bird affection has been observed only recently in a number of cases, caused either by WNV lineages already circulating in Europe [5-8] or by newly introduced lineages [5,9].

One of the hallmarks of WNV epidemiology in North America is that native wild birds are largely affected, in contrast with the low impact of associated disease in wild birds in the Old World [3]. It remains unclear whether this difference is due to the intrinsic pathogenicity of the different viruses found in each continent, or, alternatively, to the differing susceptibility of Palearctic vs. Nearctic bird species to WNV infection. However, while the effects of WNV infection on North American bird species have been intensively studied and described in a number of reports [10-15]), experimental studies on indigenous wild birds are lacking for European birds and WNV strains.

The red-legged partridge (Alectoris rufa) is a gallinaceous bird native to the Iberian Peninsula, widely distributed in South Western Europe, and has been introduced to southern England and the Canary Islands [16]. The species plays a key role in Spanish Mediterranean ecosystems and together with the European rabbit (Oryctolagus cuniculus) constitutes a staple prey for a number of endangered predators, including the Spanish Imperial eagle (Aquila adalberti) and the Iberian lynx (Lynx pardi$n u s)$. Also, it is one of the most important small game species in Central and Southern Spain, where hunting, apart from agriculture, is the most important source of income [17]. Due to the decline of natural populations of this species in most of its distribution range, partridges are raised intensively in outdoor operations and released for hunting purposes and for restocking natural populations [18]. The susceptibility of this species to WNV infection is unknown. However, a recent study reported an outbreak of clinical disease in North America caused by WNV infection in Chukar partridges (Alectoris chukar) [19], a species closely related to the red-legged partridge. These data prompted us to investigate the effects of WNV infection in European red-legged partridges. For that purpose we selected two Western Mediterranean strains of WNV: Morocco/2003 and Spain/2007, isolated in the region corresponding to the natural geographic range of red-legged partridges. Both strains are highly related phylogenetically [20]. The present study describes the course of an experimental infection of red-legged partridges with the two Western Mediterranean West Nile virus strains selected. The occurrence of direct contact transmission was also assessed.

\section{Materials and methods}

\section{Viruses and virus preparations}

The viruses used in this study were WNV Spain/2007 (strain GE-1b/B, GenBank acc. nº FJ766331) [20] and
WNV Morocco/2003 (strain 04.05, GenBank acc. ${ }^{\circ}$ : AY701413) [21]. These two strains are highly related phylogenetically, differing in 13 amino acid positions throughout the complete genome (3433 amino acid residues), one of them located at the $\mathrm{NS}_{249}$. This site has been involved in genetic modulation of WNV pathogenicity, using American crows (Corvus brachyrhynchos) as avian model of WNV disease [22]. For preparation of inocula, WNV Spain/2007 was cultivated in BSR cells (clone of BHK-21 cell line) and WNV strain Morocco/ 2003 was cultivated in Vero cells. Both strains were titrated by plaque assays in Vero cells as previously described [23]. Virus titers are given in pfu (plaqueforming units) per mL. WNV Spain/2007 and Morocco/ 2003 strains of low passage number ( 3 and 5 cell culture passages, respectively) were used for inoculations. Complete nucleotide sequences of both viruses were analyzed prior to inoculation to ascertain that the viruses inoculated had nucleotide sequences identical to those available in GenBank.

\section{Experimental inoculations in red-legged partridges}

Recently hatched red-legged partridge chicks $(\mathrm{n}=36)$ were obtained from a commercial breeder and raised in the experimental farm of the Instituto de Investigación en Recursos Cinegéticos (IREC) until they were six weeks of age. Prior to the experiment, all individuals were tested serologically (using a commercially available competition ELISA as described below) and virologically (by real-time RT-PCR as described below) to ensure that exposure to WNV had not occurred. The partridges were transported to the biosafety level 3 (BSL-3) facilities in the CISA and randomly assigned to experimental groups, that were housed in wire mesh cages with absorbent floor that was changed daily. The birds were provided with a commercial diet for game birds and water ad libitum throughout the experiment. After five days for acclimatization, two groups composed of 10 red-legged partridges each were inoculated subcutaneously $\left(10^{4} \mathrm{pfu} /\right.$ individual $)$ with either WNV Spain/ 2007 or WNV Morocco/2003 diluted in up to $0.1 \mathrm{~mL}$ in Dulbecco's Minimum Essential Medium (DMEM) (supplemented with $2 \mathrm{mM}$ L-glutamine, $100 \mathrm{U} / \mathrm{mL}$ penicillin and $100 \mu \mathrm{g} / \mathrm{mL}$ streptomycin). All partridges were in their seventh week of age when they were inoculated. Both groups were kept in separate cages $(120 \times 40 \times 40 \mathrm{~cm})$. Two groups of three non-inoculated partridges (contact groups) were kept in the same cages as inoculated individuals. One additional group of partridges $(n=10)$ was sham-inoculated with an equivalent volume of DMEM and kept in a separate cage, as an environmental control. The experiment was performed in the CISA BSL-3 animal facilities, following biosafety, animal welfare and ethical rules applicable in the EU. 


\section{Clinical follow-up and collection of samples}

Disease symptoms were observed daily for up to 10 days post-inoculation (dpi). To follow the viremia course, blood samples were collected daily during the same period from the cutaneous ulnar vein at 1, 3, 5, 7 and 9 dpi in half of the individuals, and at days 2, 4, 6, 8 and $10 \mathrm{dpi}$ in the other half (that is, alternating individuals in order to reduce animal manipulation and thus reduce unnecessary stress). A second blood sample (0.1-0.2 mL/ individual) was taken likewise in dry tubes and allowed to clot at $37^{\circ} \mathrm{C}$ for $1 \mathrm{~h}$, followed by incubation at $4^{\circ} \mathrm{C}$ overnight, in order to obtain serum for antibody detection techniques (ELISA and/or virus-neutralization tests). Similarly, oropharyngeal and cloacal swabs were taken 1 day before inoculation (i.e., -1) from all individuals, and at 4, 6, 10 and $14 \mathrm{dpi}$ in half of the individuals of each group of inoculated partridges, and 3, 5, 7 and $14 \mathrm{dpi}$ in the other half. Blood samples were collected directly in sterile polypropylene tubes filled with 0.9 mL BA-1 diluent (Hanks M-199 salts, 0.05 M Tris, $\mathrm{pH} 7.6,1 \%$ bovine serum albumin, $0.35 \mathrm{~g} / \mathrm{L}$ of sodium bicarbonate, 100 units $/ \mathrm{mL}$ of penicillin, $100 \mu \mathrm{g} / \mathrm{mL}$ of streptomycin, $1 \mu \mathrm{g} / \mathrm{mL}$ of amphotericin B) and stored at $-70^{\circ} \mathrm{C}$ until analysis. Swab samples were placed in sterile polypropylene tubes filled with $1 \mathrm{~mL}$ of Hank's balanced solution containing $10 \%$ glycerol, $200 \mathrm{U} / \mathrm{mL}$ penicillin, $200 \mu \mathrm{g} / \mathrm{mL}$ strepctomycin, $100 \mathrm{U} / \mathrm{mL}$ polymixin B sulphate, $250 \mu \mathrm{g} / \mathrm{mL}$ gentamicin and $50 \mathrm{U} / \mathrm{mL}$ nystatin and also stored at $-70^{\circ} \mathrm{C}$ until analysis. Contact partridges were sampled (both for blood and cloacal/oropharyngeal swab) at days $-1,6$, and 10 dpi. Following death, partridges were collected and necropsied within $<18 \mathrm{~h}$. Two individuals of each contact group were euthanized humanely by intravenous injection of embutramide (T61 ${ }^{\circledR}$, Intervet - Schering-Plough, Madrid, Spain) on day $10 \mathrm{dpi}$ and submitted for full necropsy. During necropsy, care was taken to avoid cross-contamination of tissues by use of single use scalpels and forceps. After the 10 day period, additional serum samples for the detection of specific antibodies against WNV in surviving partridges were collected on 12, 14, and $20 \mathrm{dpi}$, in inoculation, contact and control groups.

\section{Viremia and WNV genome detection assays}

Viremia was measured in blood (collected in BA-1 diluent) by standard plaque-formation assays as described [23] while viral genome load was measured in blood (collected in BA-1 diluent) by semiquantitative real-time RT-PCR, using a previously described method [24] with slight modifications, using an internal control. Briefly, nucleic acids were extracted from BA-1-diluted blood samples $(0.1 \mathrm{~mL})$ using Biosprint-15 automated extraction (QIAGEN, Valencia, CA, USA), and $4 \mu \mathrm{L}$ ( $4 \%$ of total eluate) of each extract, in $25 \mu \mathrm{L}$ final volume, was subjected to real-time RT-PCR amplification using the QuantiTect Probe RT-PCR kit (QIAGEN) and following manufacturer's instructions. The mix included primers (WNV-LCV-F1: 5'-GTGATCCATGTAAGCCCTCAGAA-3' and WNV-LCV-R1: 5'-GTCTGACATTGGGC TTTGAAGTTA-3') at $0.4 \mu \mathrm{M}$ final concentration, and a FAM-labelled TaqMan-MGB probe (WN-LCV-S1: 5'FAM-AGGACCCCACATGTT-3'-MGB) at $0.25 \mu \mathrm{M}$ final concentration, specific for detection of lineage $1 \mathrm{WNV}$, as well as primers (ACT F 1005-1029: 5'-CAGCACAATGAAGATCAAGATCATC-3', and ACT R 1135-1114: 5'-CG GACTCATCGTACTCCTG CTT-3') and JOE-labelled TaqMan probe (ACT P 1081-1105: 5'JOE-TCGCTGTCCACCTTCCAGCAGATGT-BBQ) for detection of an internal control ( $\beta$-actin) as described [25] in order to control for the presence and integrity of RNA isolated from each preparation. Amplification conditions consisted of a first reverse-transcription step at $50^{\circ} \mathrm{C}$ for $30 \mathrm{~min}$, followed by $15 \mathrm{~min}$ at $95^{\circ} \mathrm{C}$ ("hot start") and 45 cycles of $15 \mathrm{~s}$ at $95^{\circ} \mathrm{C}$ and 1 min at $60^{\circ} \mathrm{C}$. Tissues, oropharyngeal and cloacal swabs were examined for the presence of viral genome using the same RNA extraction method and real-time RTPCR described above, but following a preparation step consisting of homogenization for $2 \mathrm{~min}$ at 30 cycles/s in 90\% phosphate-buffered saline (PBS) using a Tissuelyser homogenizer, QIAGEN, followed by clarification at 850 $\times g 10 \mathrm{~min}$. in the case of tissues, and elution for $3 \mathrm{~h}$ at $4^{\circ} \mathrm{C}$ in $1 \mathrm{~mL} \mathrm{BA}-1$ diluent (see above), followed by clarification at $9500 \times g 5 \mathrm{~min}$, in the case of oropharyngeal and cloacal swabs.

\section{Antibody detection assays}

Serum antibodies to WNV were detected by a commercially available competition ELISA suitable for measurement of antibodies to WNV in serum of wild birds following manufacturer's instructions (ID Screen ${ }^{\odot}$ West Nile Competition, IdVet, Montpellier, France). Virus-neutralizing antibody titers were measured by a micro-virus neutralization test as described [26]. Positive neutralization was considered for each inoculated well when complete absence of $\mathrm{CPE}$ was observed in the cell monolayer.

\section{Statistical analysis}

Comparison of survival rates between groups of partridges inoculated with Morocco/2003 and Spain/2007 WNV strains was carried out by using the GehanBreslow-Wilcoxon method [27]. Viremia and genome load data between groups of partridges inoculated with Morocco/2003 and Spain/2007 WNV strains were compared using Student's $t$ test for independent groups. 


\section{Results}

Both WNV strains assayed were pathogenic for redlegged partridges. All inoculated partridges showed clinical signs (e.g. loss of appetite, ruffled feathers, paralysis, and unresponsiveness), yet those infected with Morocco/2003 were more severely affected than those infected with Spain/2007. Firstly, the onset of symptoms began one day earlier ( 4 vs. $5 \mathrm{dpi}$ ) in partridges inoculated with Morocco/2003 than in those inoculated with Spain/2007. Secondly, mortality was higher (70\% vs. $30 \%$ ) and started earlier (5 vs. 6 dpi) with Morocco/ 2003 than with Spain/2007 (Figure 1). The differences observed in survival rates over time between both groups of inoculated partridges were statistically significant $(\mathrm{p}<0.05)$. Clinical signs and mortality ceased by $9 \mathrm{dpi}$ in both inoculated groups. Viral genome was detectable from 1 to $7 \mathrm{dpi}$ (Figure 2a) in both inoculations. Viremia was detectable between 1 and 6 dpi for Spain/2007 and slightly longer (up to $7 \mathrm{dpi}$ ) for Morocco/2003. Peak viremia titers, and peak viral genome loads were found at $3 \mathrm{dpi}$ for both isolates. Mean peak viremia was higher after inoculation with Morocco/2003 $\left(10^{7.2} \mathrm{pfu} / \mathrm{mL}\right)$ than with Spain $/ 2007\left(10^{6.9} \mathrm{pfu} / \mathrm{mL}\right)$ (Figure 2b), similarly to what occurred with viral genome loads (Figure 2a) although in both cases the differences between both groups were not statistically significant ( $p>0.05)$. All surviving partridges developed WNVneutralizing antibodies (NtAb) (Figure 3), which were observed at $10 \mathrm{dpi}$ or later. In inoculated partridges, specific antibodies to WNV as revealed by competitive ELISA were observed slightly earlier (6 dpi) than NtAb (Figure 3). Oral and cloacal virus shedding was observed between 3 and 7 dpi for both viruses. Virus shedding was more consistently found in oropharyngeal than in cloacal swabs for both strains, particularly in early stages (3 dpi, Figure 4 ).

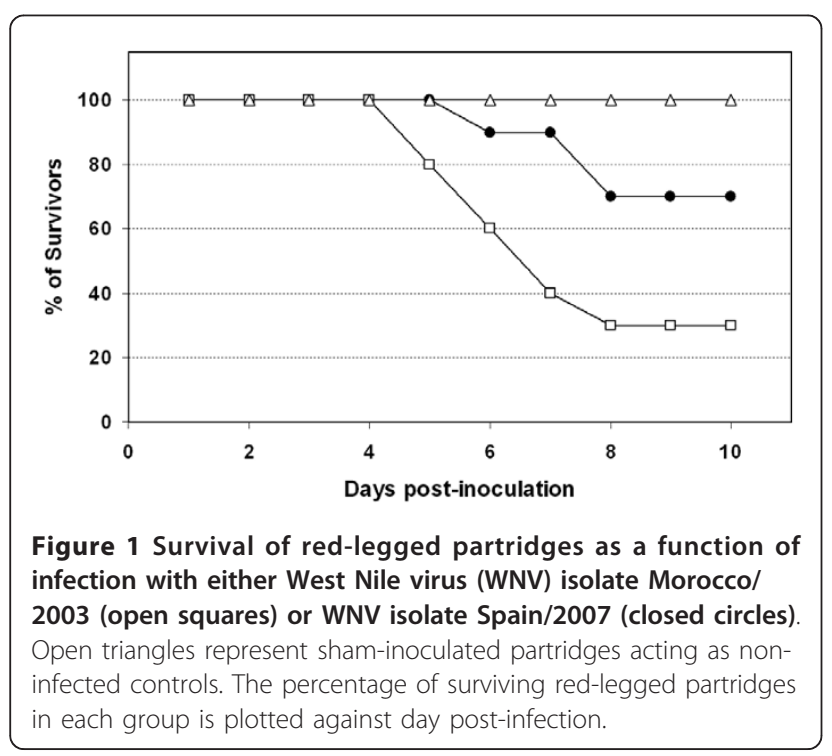

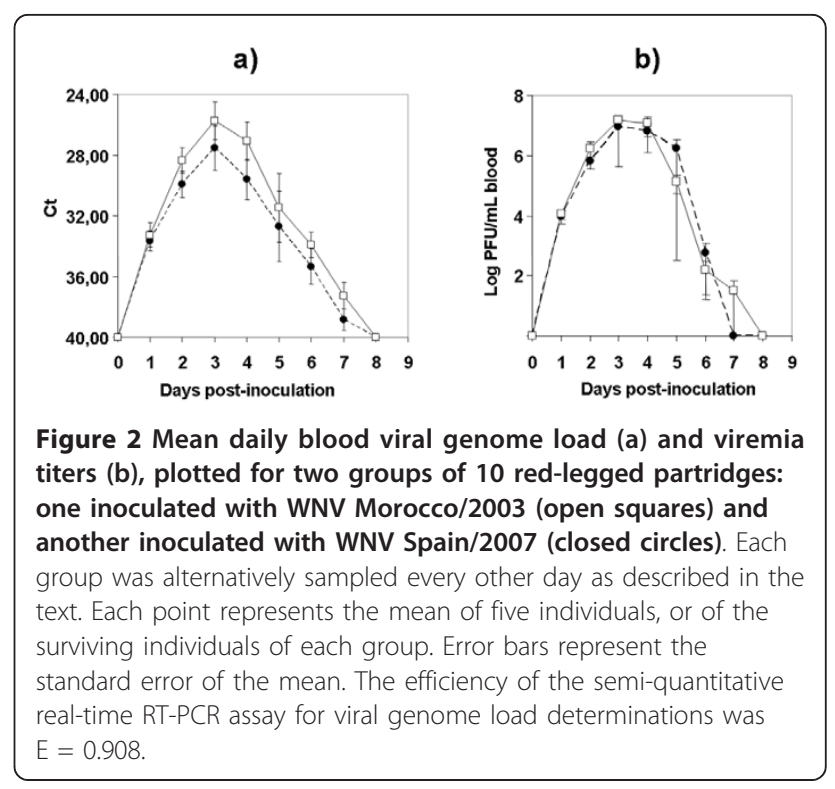

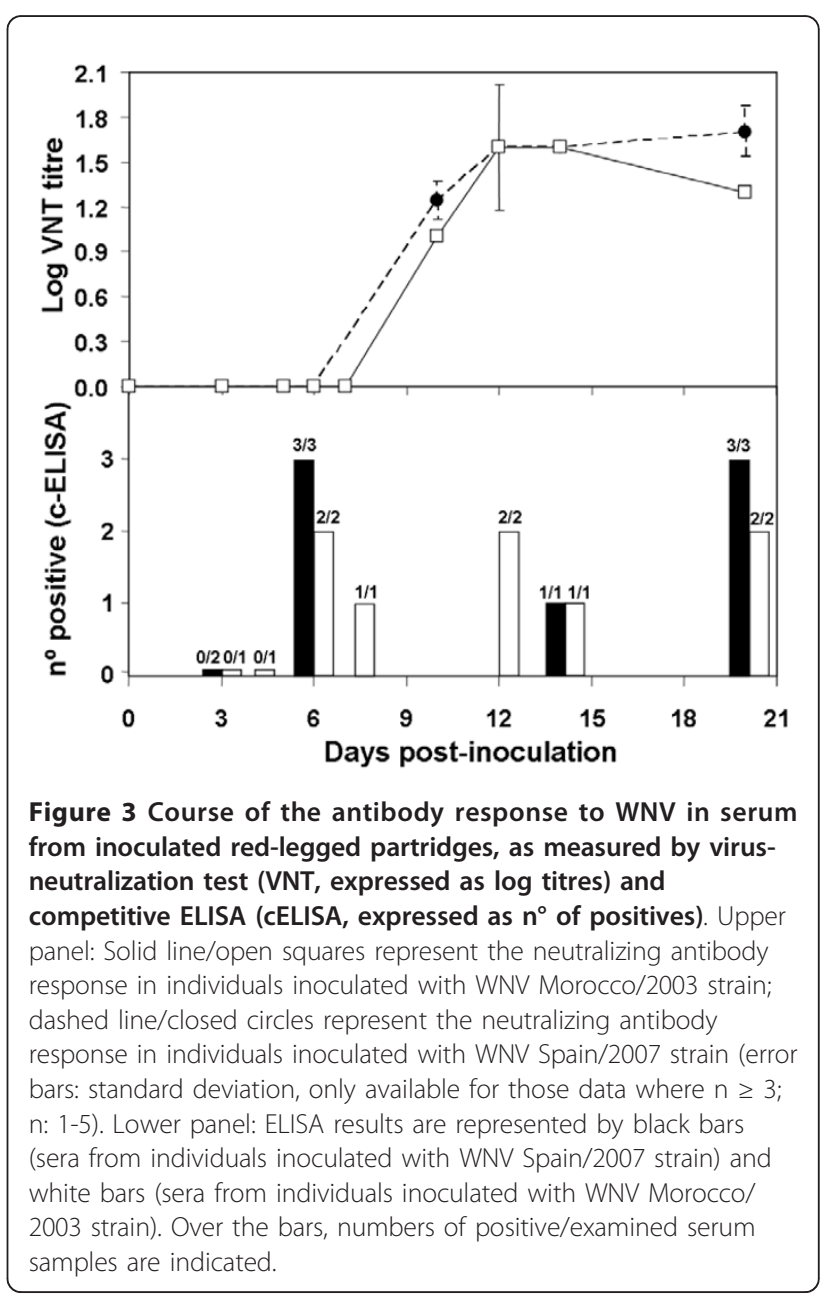



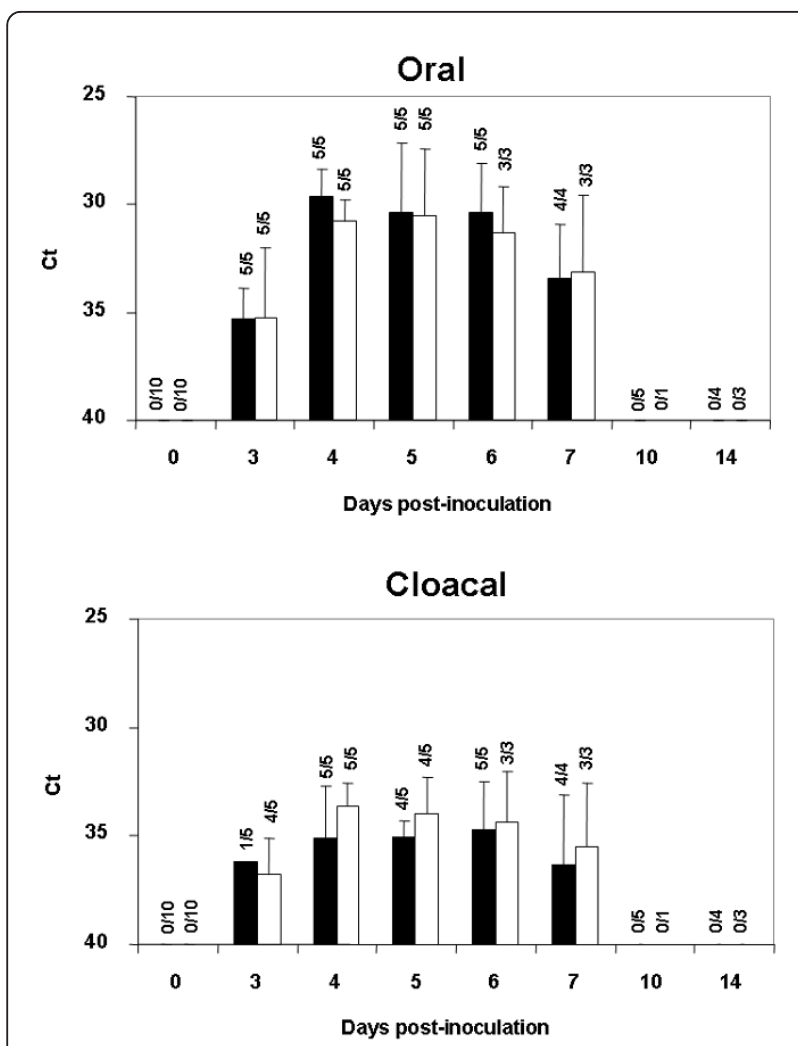

Figure 4 Viral shedding through the oral (upper panel) and fecal (lower panel) routes, as estimated by real-time RT-PCR analysis of the oropharyngeal and cloacal swabs, respectively, taken at different days post-inoculation of WNV Spain/2007 strain (black bars) or WNV Morocco/2003 strain (white bars). Error bars represent standard deviation of the means. Over the bars, numbers of positive/examined swab samples are indicated.

Post-mortem examination of lethally infected partridges revealed systemic infection, as the virus was detected in the brain, heart, spleen and liver by means of real time RT-PCR (Table 1). Upon necropsy, infected partridges were in poor body condition. Gross lesions were similar in both WNV-inoculated groups, and were characterized mainly by ascites, diffuse pallor of the myocardium, enlarged liver and petechia on the renal surface, injected blood vessels in the intestinal tract, and, in three birds, congestion of superficial cerebral vessels.

The virus was not detectable in blood of noninoculated contact partridges during the whole course of the experiment, and, furthermore, these partridges did not seroconvert, as assessed either by competition ELISA or by virus-neutralization test (data not shown), further supporting the absence of infection. Oropharyngeal and cloacal swabs from these contact partridges also remained negative until they were euthanized for tissue examination. Brain, heart, spleen and liver samples examined from these birds resulted negative for WNV genome by real-time RT-PCR at $10 \mathrm{dpi}$ (Table 1).
Table 1 Summary of the WNV genome detection by realtime RT-PCR performed on tissues from inoculated redlegged partridges

\begin{tabular}{llllll}
\hline \multirow{2}{*}{$\begin{array}{l}\text { Individual } \\
\text { identification }\end{array}$} & Inoculum & Brain & Heart & Kidney & Spleen \\
\cline { 3 - 6 } & & & & & \\
10 & Spain/2007(*) & Pos & Pos & Pos & Pos \\
11 & Spain/2007(*) & Pos & Pos & Pos & Pos \\
13 & Spain/2007(*) & Pos & Pos & Pos & Pos \\
20 & Morocco/2003(*) & Pos & Pos & Pos & Pos \\
24 & Morocco/2003(*) & Pos & Pos & Pos & Pos \\
29 & Morocco/2003(*) & Pos & Pos & Pos & Pos \\
\hline
\end{tabular}

* Contact (non-inoculated cage-mate) controls gave negative results upon necropsy at $10 \mathrm{dpi}$ in all tissues analyzed by real-time RT-PCR.

**Samples were considered positive ("Pos") at Ct $\geq 40.0$.

Sham-inoculated partridges (environmental control group) did not show symptoms or mortality, and remained negative for virus genome and antibody detection throughout the experiment.

\section{Discussion}

The results of this work demonstrated that the red-legged partridge is susceptible to WNV disease, and provides further evidence that some European wild bird species can be clinically affected by WNV. This concept is supported by recent reports describing field WNV cases in different wild bird species in Europe. While previous work reported three types of European eagles (golden eagle -Aquila chrysaetos-, Spanish imperial eagle -Aquila adalberti- and Bonnelli's eagle -Hieraaetus fasciatus-) clinically affected by WNV in Spain [6,7], the disease was also described in goshawks (Accipiter gentilis), sparrow hawks (Accipiter nisus) and geese (Anser anser) in Hungary [5], sparrow hawks in Austria [9], and house sparrows (Passer domesticus) and magpies (Pica pica) in the Camargue region of France [8]. Just prior to the arrival of WNV to North America in 1999, migrating storks and domestic geese were adversely affected by WNV infection in Israel [28]. Subsequent experimental studies on domestic geese conducted in Israel confirmed their susceptibility to WNV disease [29]. Nevertheless, to our knowledge, the present study is the first reporting an experimental infection with WNV in a European wild bird showing symptoms of disease.

In addition, our results demonstrate experimentally that at least some Euro-Mediterranean WNV strains are pathogenic in an indigenous wild bird species. Previous results showed that one of the strains used in this experiment (Morocco/2003) was as pathogenic for mice as the NY99 prototype strain [20]. Thus, the apparently limited wild bird morbidity caused by WNV in Europe, as compared to the high virulence for WNV in wild 
birds in North America, demands an explanation accounting for the fact, reflected in this work, that at least some Euro-Mediterranean WNV strains are highly pathogenic for certain indigenous wild birds such as the red-legged partridge. In the European context the apparently mild consequences of WNV disease for wild birds would likely arise from the difficulties inherent to the surveillance of mortality events in the affected wild bird species rather than from low pathogenicity of local WNV strains, or from low susceptibility of indigenous wild birds.

In this work, contact partridges did not show disease symptoms, and remained negative both for virus detection in blood and/or tissues, as well as for WNV-specific antibodies. Thus, direct WNV transmission did not occur in the experimental conditions used in this assay, despite close interaction between inoculated and noninoculated partridges. While contact transmission has been demonstrated for certain avian species [29], evidence of this is lacking for other wild bird species. For instance, in an exhaustive study evaluating WNV transmission dynamics in 25 different avian species, contact (cage-mate) transmission was observed in only four species (Blue Jays, Black-billed Magpies, American Crows and Ring-billed Gulls). Interestingly, contact transmission was not observed in the two species of Galliformes evaluated (Japanese Quail and Northern Bobwhite) [10]. In a different study addressing long-term immunity in House Sparrows as important amplifying hosts for WNV, contact transmission was not observed in this species [14]. Viral shedding by the oral and faecal routes occurred in all the inoculated partridges monitored, so the absence of contact transmission in this model needs further investigation, in particular if this finding is attributable to the avian model, or to the viral isolates used.

New animal models of WNV infection are of interest not only for virulence studies but also for antiviral and vaccine development [30]. This work demonstrates that the red-legged partridge constitutes a suitable avian model of WNV infection, since this bird species is not only susceptible to infection and disease but is also easy to obtain, can be raised in captivity, and is relatively easy to handle. In addition, our data demonstrate that the redlegged partridge could act as amplifying host for WNV, as shown by the maximum viremia levels attained during the experiment (approximately $10^{7.0} \mathrm{pfu} / \mathrm{mL}$ blood), clearly above the established threshold level of infectious viremia, estimated at $10^{5.0} \mathrm{pfu} / \mathrm{mL}$ of blood [10].

The red-legged partridge is indigenous to the Mediterranean region, where it constitutes a key prey species for many predators. Those predators feeding on infected partridges or carrion eaters feeding on their carcasses could be at risk of infection since non-vectored transmission of WNV through ingested infected food has been documented [10,31,32]. In Spain, some endangered species such as the Golden eagle, the Bonnelli's eagle and the Spanish Imperial eagle prey regularly on redlegged partridges and have been shown to be susceptible to WNV-associated disease [6,7]. Thus the occurrence of WNV outbreaks in red-legged partridges could potentially constitute a risk for the conservation of these endangered species.

The red-legged partridge also represents an important small game species being intensively raised in open air facilities and released into the wild for restocking and hunting purposes. The species also exists in the South of the UK and the Canary Islands, where there is concern about the introduction and spread of WNV. A closely related partridge species (Chukar partridge) is also susceptible to WNV-associated disease in North America, where farms raising these wild birds have suffered outbreaks of the disease [19]. Besides their economic importance, partridge farms could play a relevant role for public health since in case of a hypothetical WNV outbreak, and provided the presence of suitable mosquito species with a broad host spectrum, farmed red-legged partridges could potentially act as the reservoir for accidental transmission of WNV into humans and horses. Suitable mosquito vectors as Culex pipiens are abundant in the red-legged partridges' natural habitat as well as in the farms (unpublished observation). Thus, in surveillance programs, WNV disease should be considered as a potential hazard for farms producing red-legged partridges. This is of particular importance bearing in mind that eventually these captive-raised partridges are to be released into the wild.

In the experimental work described here, the viral strains (Morocco/2003, and Spain/2007) used to inoculate differed in 13 out of 3433 amino acid residues (99.62\% amino acid identity), one of them being $\mathrm{NS}_{249}$. This site appears to play a role in the genetic modulation of pathogenicity for wild birds, as substitution of threonine $(\mathrm{T})$ by proline $(\mathrm{P})$ in a moderately pathogenic WNV strain (Ken98) resulted in an increase in virulence for American crows, whereas, the opposite change $(\mathrm{P} 249 \mathrm{~T})$ resulted in a decrease in virulence for the highly pathogenic NY99 strain in the same hosts [22]. This site is occupied by $\mathrm{T}$ in Morocco/2003, and by $\mathrm{P}$ in Spain/2007. We showed recently in a mouse model that Morocco/2003 is more pathogenic than Spain/2007 [20]. Here we confirm and extend this observation to a wild bird species. This suggests that a proline residue in position 249 of the NS3 protein is not sufficient to enhance virulence for any given WNV strain. Possibly, other residues that differ between both strains are also playing a role in the observed pathogenicity, and could have produced apparent discrepancies with previous studies using infectious clones in American crows [22,33]. The NS3 ${ }_{249}$-P genotype has arisen recently in the 
Western Mediterranean region. This WNV genotype has been involved in recent outbreaks in northeastern Italy [34], in which WNV strains have been similar to those used in the present study [20]. An assessment of the pathogenicity of these recent Italian isolates would provide further insight into the epidemiology of the $\mathrm{NS}_{249}$ genotype in the Western Mediterranean area.

The pathogenicity of the Spanish WNV isolate was less than that of another Western Mediterranean strain, i.e., Morocco/2003, not only in a mouse model, but also in the red-legged partridge. This finding could explain why this disease has remained essentially silent in Spain to date, and provide a possible mechanism accounting for the occurrence of sporadic WNV outbreaks interspersed by silent WNV circulation in some regions such as the Western Mediterranean. Small genetic changes in the virus genome (T249P at NS3, or others), could substantially reduce the pathogenicity of circulating viruses, and vice-versa. However, other factors not linked to the virus, but to host susceptibility and vectors, could also contribute to this epidemiological pattern, the relative importance of which merits further investigations.

\section{Acknowledgements}

We thank the personnel of the experimental farm of the University of Castilla - La Mancha, "La Galiana" for their effort in this study. We would like to acknowledge the Junta de Comunidades de Castilla - La Mancha (JCCM) for their support. This study is a contribution of the epidemiological network of rehabilitation centers in the community of Castilla - La Mancha, and the REVISA network, and has been supported by the project PAC08-0296-7771 (JCCM), and from INIA-MARM funds (INIA CC08-020). Elena Sotelo is a fellow from INIA. Elisa Perez Ramirez is a fellow from the National Research Council (CSIC) and Ana Valeria Gutierrez is a fellow from JCCM.

\section{Author details}

'Centro de Investigación en Sanidad Animal del Instituto Nacional de Investigación y Tecnología Agraria y Alimentaria (CISA-INIA), Ctra Algete-El Casar, s/n, 28130 Valdeolmos (Madrid), Spain. ${ }^{2}$ Instituto de Investigación en Recursos Cinegéticos IREC (CSIC-UCLM-JCCM), Ronda de Toledo s/n, 13005 Ciudad Real, Spain. ${ }^{3}$ Biopharma Laboratory, Km 2 Route de Casablanca, BP 4569 Rabat Akkari, Morocco. ${ }^{4}$ Centro de Estudios de Rapaces Ibéricas CERI (JCCM), Sevilleja de la Jara, 45671 Sevilleja de la Jara, Spain.

\section{Authors' contributions}

ES prepared the inocula, carried out animal experimental work, and performed most virological, molecular and serological analyses. AVG performed animal experimental work and participated in the pathological examination of post-mortem specimens. JD performed animal experimental work and participated in a part of the molecular analyses. FL performed animal experimental work, carried out part of the serological tests and performed the statistical analysis. ME prepared one of the viral stocks used in the inoculations and helped in the design of the study. EP participated in the animal experimental work. JMB raised the red-legged partridges. UH participated in the design and coordination of the study, red-legged partridge raising and pathological examination of post-mortem specimens. MAJ conceived of the study, participated in its design and coordination, and drafted the manuscript. All authors read and approved the final manuscript.

\section{Competing interests}

The authors declare that they have no competing interests.

Received: 20 April 2010 Accepted: 9 September 2010 Published: 18 January 2011
References

1. Gould EA, de Lamballerie X, Zanotto PM, Holmes EC: Origins, evolution, and vector/host coadaptations within the genus Flavivirus. Adv Virus Res 2003, 59:277-314.

2. Kramer LD, Styer LM, Ebel GD: A global perspective on the epidemiology of West Nile virus. Annu Rev Entomol 2008, 53:61-81.

3. Brault AC: Changing patterns of West Nile virus transmission: altered vector competence and host susceptibility. Vet Res 2009, 40:43.

4. Zeller HG, Schuffenecker I: West Nile virus: an overview of its spread in Europe and the Mediterranean basin in contrast to its spread in the Americas. Eur J Clin Microbiol Infect Dis 2004, 23:147-156.

5. Bakonyi T, Ivanics E, Erdelyi K, Ursu K, Ferenczi E, Weissenbock H, Nowotny N: Lineage 1 and 2 strains of encephalitic West Nile virus, central Europe. Emerg Infect Dis 2006, 12:618-623.

6. Hofle U, Blanco JM, Crespo E, Naranjo V, Jimenez-Clavero MA, Sanchez A, de la Fuente J, Gortazar C: West Nile virus in the endangered Spanish imperial eagle. Vet Microbiol 2008, 129:171-178.

7. Jimenez-Clavero MA, Sotelo E, Fernandez-Pinero J, Llorente F, Blanco JM, Rodriguez-Ramos J, Perez-Ramirez E, Hofle U: West Nile virus in golden eagles, Spain, 2007. Emerg Infect Dis 2008, 14:1489-1491.

8. Jourdain E, Schuffenecker I, Korimbocus J, Reynard S, Murri S, Kayser Y, Gauthier-Clerc M, Sabatier P, Zeller HG: West Nile virus in wild resident birds, Southern France, 2004. Vector Borne Zoonotic Dis 2007, 7:448-452.

9. West Nile Virus: Austria. [http://www.defra.gov.uk/foodfarm/farmanimal/diseases/ monitoring/documents/wnv-austria.pdf], (accessed December 30th 2010).

10. Komar N, Langevin S, Hinten S, Nemeth N, Edwards E, Hettler D, Davis B, Bowen R, Bunning M: Experimental infection of North American birds with the New York 1999 strain of West Nile virus. Emerg Infect Dis 2003, 9:311-322.

11. Nemeth NM, Oesterle PT, Bowen RA: Passive immunity to West Nile virus provides limited protection in a common passerine species. Am J Trop Med Hyg 2008, 79:283-290.

12. Nemeth N, Young G, Ndaluka C, Bielefeldt-Ohmann H, Komar N, Bowen R: Persistent West Nile virus infection in the house sparrow (Passer domesticus). Arch Virol 2009, 154:783-789.

13. Langevin SA, Brault AC, Panella NA, Bowen RA, Komar N: Variation in virulence of West Nile virus strains for house sparrows (Passer domesticus). Am J Trop Med Hyg 2005, 72:99-102.

14. Nemeth NM, Oesterle PT, Bowen RA: Humoral immunity to West Nile virus is long-lasting and protective in the house sparrow (Passer domesticus). Am J Tropl Med Hyg 2009, 80:864-869.

15. Nemeth N, Gould D, Bowen R, Komar N: Natural and experimental West Nile virus infection in five raptor species. J Wildl Dis 2006, 42:1-13.

16. Blanco-Aguiar JA, Virgós E, Villafuerte R: Perdiz Roja (Alectoris rufa). In Atlas de las aves reproductoras de España. Edited by: Martí R, Del Moral, JC. Madrid (Spain): Dirección General de Conservación de la Naturaleza y Sociedad Española de Ornitología; 2003:212-213.

17. Bernabeu RL: Evaluación económica de la caza en Castilla-La Mancha. PhD thesis Universidad de Castilla-La Mancha; 2000

18. Aebischer NJ, Potts GR: Red-legged partridge (Alectoris rufa). In Birds in Europe: Their Conservation Status. Edited by: Tucker GM, Heath MF, Tomialojc L. Cambridge, UK: Birdlife International; 1994.

19. Wunschmann A, Ziegler A: West Nile virus-associated mortality events in domestic Chukar partridges (Alectoris chukar) and domestic Impeyan pheasants (Lophophorus impeyanus). Avian Dis 2006, 50:456-459.

20. Sotelo E, Fernandez-Pinero J, Llorente F, Aquero M, Hoefle U, Blanco JM, Jimenez-Clavero MA: Characterization of West Nile virus isolates from Spain: New insights into the distinct West Nile virus eco-epidemiology in the Western Mediterranean. Virology 2009, 395:289-297.

21. Schuffenecker I, Peyrefitte CN, el Harrak M, Murri S, Leblond A, Zeller HG: West Nile virus in Morocco, 2003. Emerg Infect Dis 2005, 11:306-309.

22. Brault AC, Huang CY, Langevin SA, Kinney RM, Bowen RA, Ramey WN, Panella NA, Holmes EC, Powers AM, Miller BR: A single positively selected West Nile viral mutation confers increased virogenesis in American crows. Nat Genet 2007, 39:1162-1166.

23. Payne AF, Binduga-Gajewska I, Kauffman EB, Kramer LD: Quantitation of flaviviruses by fluorescent focus assay. J Virol Methods 2006, 134:183-189.

24. Jimenez-Clavero MA, Aguero M, Rojo G, Gomez-Tejedor C: A new fluorogenic real-time RT-PCR assay for detection of lineage 1 and lineage 2 West Nile viruses. J Vet Diagn Invest 2006, 18:459-462. 
25. Toussaint JF, Sailleau C, Breard E, Zientara S, De Clercq K: Bluetongue virus detection by two real-time RT-qPCRs targeting two different genomic segments. J Virol Methods 2007, 140:115-123.

26. Figuerola J, Jimenez-Clavero MA, Rojo G, Gomez-Tejedor C, Soriguer R: Prevalence of West Nile virus neutralizing antibodies in colonial aquatic birds in southern Spain. Avian Pathol 2007, 36:209-212.

27. Gehan EA: A generalized Wilcoxon test for comparing arbitrarily singlycensored samples. Biometrika 1965, 52:203-223.

28. Malkinson M, Banet C: The role of birds in the ecology of West Nile virus in Europe and Africa. Curr Top Microbiol Immunol 2002, 267:309-322.

29. Banet-Noach C, Simanov L, Malkinson M: Direct (non-vector) transmission of West Nile virus in geese. Avian Pathol 2003, 32:489-494.

30. Nalca A, Fellows PF, Whitehouse CA: Vaccines and animal models for arboviral encephalitides. Antiviral Res 2003, 60:153-174.

31. Garmendia AE, Van Kruiningen HJ, French RA, Anderson JF, Andreadis TG, Kumar A, West AB: Recovery and identification of West Nile virus from a hawk in winter. J Clinl Microbiol 2000, 38:3110-3111.

32. Kuno G: Transmission of arboviruses without involvement of arthropod vectors. Acta Virol 2001, 45:139-150.

33. Brault AC, Langevin SA, Bowen RA, Panella NA, Biggerstaff BJ, Miller BR, Komar N: Differential virulence of West Nile strains for American crows. Emerg Infect Dis 2004, 10:2161-2168.

34. Barzon L, Franchin E, Squarzon L, Lavezzo E, Toppo S, Martello T, Bressan S, Pagni S, Cattai M, Piazza A, Pacenti M, Cusinato R, Palù G: Genome sequence analysis of the first human West Nile virus isolated in Italy in 2009. Euro Surveill 2009, 14:41938.

doi:10.1186/1297-9716-42-11

Cite this article as: Sotelo et al:: Pathogenicity of two recent Western Mediterranean West Nile virus isolates in a wild bird species indigenous to Southern Europe: the red-legged partridge. Veterinary Research 2011 42:11.

\section{Submit your next manuscript to BioMed Central and take full advantage of:}

- Convenient online submission

- Thorough peer review

- No space constraints or color figure charges

- Immediate publication on acceptance

- Inclusion in PubMed, CAS, Scopus and Google Scholar

- Research which is freely available for redistribution

Submit your manuscript at www.biomedcentral.com/submit 